“KOSnเด• JIK. Vol. 2 No. 1 Maret 2014

\title{
PENGARUH KONSUMSI KULIT MANGGIS TERHADAP PENURUNAN KADAR GULA DARAH PADA PENDERITA DIABETES MELLITUS DI DESA METESEH BOJA KENDAL TAHUN 2013
}

\author{
Oleh : \\ Budi Herminto ${ }^{1}$ Diyono ${ }^{2}$ Shinta Dewi Kusuma ${ }^{3}$
}

\begin{abstract}
Background. Prevalensidiabetes mellitus in Indonesia potentially increased dramatically from 8.4 million people in 2000 to 21.3 million people in 2030 . Diabetes mellitus may develop so bad with various complicated, diabetus mellitus of year to year growing a wide range of treatment options including nonmedicinal chemistry ( Hebal ). One type of therapy is continuously studied using mangosteen peel efectivitness.

Research Objectives. Knowing the effect of the consumption of mangosteen rind to decrease blood sugar in the Village District of Boja Meteseh Kendal

This is a research Methods. Quasi experiment with pre- post design eksperimental.Responden study are all patients with diabetes mellitus in the village of Boja Meteseh many as 17 people , as many as 16 samples taken. Sampling technic used was simple random sampling. Data obtained by the method of observation of assessing the results of measurements of blood sugar levels before and after taking of mangosteen skin . The data were processed with pairet $t$ - test $(p=0.05)$ using SPSS 18 .

Results : ( 1 ) blood sugar levels before taking mangosteen peel at the most in the range of $301-400 \mathrm{mg} / \mathrm{dL}$ with a percentage of $43.75 \%$, the lowest blood sugar levels in the category of $501-600 \mathrm{mg} / \mathrm{dL}$, with a percentage of $12.5 \%$, with an average value of 392.63 . ( 2 ) Blood sugar levels after consumption of mangosteen peel at the most in the range of $200-300 \mathrm{mg} / \mathrm{dL}$, the percentage of blood sugar levels are the lowest in the category of $501-600 \mathrm{mg} / \mathrm{dL}$, with a percentage of $12.5 \%$, with an average value of $371.31 \mathrm{mg} / \mathrm{dL}$ ( 3 ) There are significant differences in blood sugar levels before and after consuming mangosteen peel with a value of $0.001 \mathrm{t}$ - Test

Conclusion : Consumption of mangosteen peel significant effect on lowering blood sugar levels by $t$ - test results of $5 \%$ ( 0.05$)$, obtained $P$ value of 0.001 .
\end{abstract}

Keywords: Blood Sugar Levels, Skin Mangosteen, Diabetes Mellitus

\section{PENDAHULUAN}

Diabetes mellitus merupakan suatu penyakit kronik yang kompleks yang berupa kelainan atau gangguan metabolisme karbohidrat, protein dan lemak dan diikuti berkembangnya komplikasi makrovaskuler, mikrovaskuler dan neurologi. (Riyadi dan Sukarmin, 2008)

Lembaga kesehatan dunia $\mathrm{WHO}$

(World Health Organization) mengingatkan prevalensi penderita diabetes mellitus di Indonesia berpotensi mengalami kenaikan drastis dari 8,4 juta orang pada tahun 2000 menjadi 21,3 juta penderita di 2030 nanti. (Edwin, 2013)

Di Jawa Tengah, berdasarkan laporan kasus diabetes mellitus ditemukan sebanyak 151.075. Tertinggi adalah di Kota Semarang yaitu sebesar 46.225 kasus 
$(30,59 \%)$ dibandingkan dengan keseluruhan Diabetes Mellitus di kabupaten/kota lain di Jawa Tengah. Sedangkan kasus tertinggi kedua adalah Kabupaten Klaten yaitu sebesar 16.067 kasus $(10,22 \%)$. Sedangkan di Boja Kendal, dilaporkan penderita diabetes mellitus cukup banyak tetapi belum diketahui data yang sebenarnya. (Dinkes Jateng, 2003) Diabetes mellitus dapat menyebabkan beberapa komplikasi yang dapat berakibat fatal sehingga memerlukan penatalaksananan yang tepat. Penatalaksanaan diabetes mellitus menurut Riyadi dan Sukarmin (2008) meliputi obatobatan hipoglikemik oral (OHO), insulin, diet, dan olahraga. Selain itu, dewasa ini mulai berkembang terapi alternatif dengan menggunakan obat herbal. Salah satu yang dikembangkan adalah menggunakan kulit manggis.

Jika di Timur Tengah terkenal dengan buah kurma yang memiliki kandungan gizi nyaris sempurna, maka di Asia buah manggis yang belakangan naik pamor.Bukan hanya karena rasanya yang lezat dan khas, tetapi kandungan antioksidan di dalamnya yang mampu menangkal pelbagai penyakit ganas separti kanker, jantung, ginjal, diabetes, bahkan AIDS.Para ilmuwan bontani menemukan khasiat unggul tersebut dalam kulit manggis.Menghebohkan, karena sejauh ini kulit manggis hanya dibuang sia-sia karena dianggap tak bermanfaat.Padahal, kandungan antioksidan dalam kulit manggis merupakan yang paling tinggi di antara buah-buah yang ada. (Yunitasari, 2011)

Manggis (mangosteen) dengan nama latin Garcinia mangostana ini berasal dari Asia Tenggara. Pohon manggis hanya bisa tumbuh di hutan dan daratan tinggi tertentu yang beriklim tropis seperti
Indonesia, Malaysia, Vietnam, Myanmar, Filipina dan Thailand serta di Hawai dan Australia Utara. Manggis juga dikenal sebagai tanaman budidaya dan merupakan salah satu tanaman buah tropika yang pertumbuhannya paling lambat, tetapi umurnya juga paling panjang. Membutuhkan 10-15 tahun untuk mulai berbuah dan tingginya mencapai 10-25 meter. (Yunitasari, 2011)

Sebagaimana halnya di Indonesia secara umum kasus diabetes mellitus cukup tinggi, secara khusus di Desa Meteseh walaupun belum ada data resmi kasus diabetes mellitus cukup banyak. Desa Meteseh merupakan salah satu desa yang berada di Kecamatan Boja Kabupaten Kendal.Hasil survey awal diperoleh data 17 orang warga yang menderita diabetes mellitus. Hasil wawancara dengan beberapa warga yang mengalami diabetus melitus, mengatakan belum pernah mengkonsumsi kulit manggis untuk menurunkan kadar gula darah. Penderita diabetes mellitus hanya mengkonsumsi obat pemberian bidan desa atau dokter yang secara ekonomi lebih mahal dibandingkan dengan kulit manggis. Berdasarkan uraian dalam latar belakang masalah di atas maka rumusan masalah pada penelitian ini adalah "Apakah konsumsi kulit buah manggis berpengaruh terhadap penurunan kadar gula darah pada penderita diabetes mellitus di Desa Meteseh Kecamatan Boja Kabupaten Kendal?"

\section{TUJUAN PENELITIAN}

Tujuan umum penelitian ini adalah untuk mengetahui pengaruh konsumsi kulit buah manggis terhadap penurunan gula darah di Desa Meteseh Kecamatan Boja Kabupaten Kendal. Adapun tujuan khusus dari penelitian adalah (1) Mengetahui kadar gula darah 
penderita diabetes mellitus sebelum mengkonsumsi kulit manggis, (2) Mengetahui kadar gula darah penderita diabetes mellitus setelah mengkonsumsi kulit manggis.

\section{METODE PENELITIAN}

Penelitian ini merupakan penelitian eksperimen semu atau quasi eksperiment dengan rancangan pre post eksperimental untuk mengetahui pengaruh pemberian konsumsi kulit manggis terhadap penurunan kadar gula darah pada penderita diabetes mellitus, dengan cara membandingkan kadar gula darah sebelum diberi kulit manggis dan setelah diberi kulit manggis.

Populasi dalam penelitian ini adalah masyarakat Desa Meteseh Kecamatan Boja Kabupaten Kendal yang menderita diabetes mellitus sebanyak 17 orang.

Sampel pada penelitian ini adalah 16. Jumlah tersebut peneliti ambil berdasar tabel krecjie, dimana jika jumlah populasi sebanyak 17 maka besar sampel adalah 16 responden dengan kriteria inklusi sebagai berikut (1) Warga Desa Meteseh Kecamatan Boja Kabupaten Kendal yang menderita DM dan bersedia untuk diteliti. (2) Hasil pemeriksaan GDS di atas normal (3) Tidak mengkonsumsi obat untuk menurunkan kadar gula darah.

Tehnik sampling yang digunakan adalah simple random sampling yaitu dengan cara acak tanpa memperhatikan strata yang ada dalam anggota populasi.

Peneliti menggunakan instrumen penelitian berupa Accu Cek. Digunakan untuk mengukur kadar gula darah sewaktu. Data pengukuran berupa data rasio yaitu nilai kadar gula darah sewaktu dalam $\mathrm{mg} / \mathrm{dl}$.

Perlakuan yang dberikan dalam penelitian ini adalah pemberian atau konsumsi kulit manggis sebanyak 3 buah ukuran sedang, 2 kali sehari selama 3 hari. Cara penyediaan obat adalah dengan mengambil 3 kulit buah manggis yang sudah kering, lalu dicuci, dan dihaluskan. Setelah itu disedu dennan air dan kemudian diminum. C lain yang dilakukan adalah den 3 kulit buah manggis ukuran sedang dengan 2 gelas air ukuran $200 \mathrm{cc}$, lalu setelah mendidih dan air tinggal sekitar 1 gelas, didinginkan dan diminum 3 kali sehari.

\section{HASIL PENELITIAN}

1. Kadar Gula Darah Sebelum Mengkonsumsi Kulit Manggis

Tabel 1. Distribusi frekuensi kadar gula darah sebelum Perlakuan

\begin{tabular}{ccc}
\hline $\begin{array}{c}\text { Kadar Gula } \\
\text { Darah }\end{array}$ & $\mathrm{f}$ & $\%$ \\
\hline $200-300 \mathrm{mg} / \mathrm{dL}$ & 3 & $18,75 \%$ \\
$301-400 \mathrm{mg} / \mathrm{dL}$ & 7 & $43,75 \%$ \\
$401-500 \mathrm{mg} / \mathrm{dL}$ & 4 & $25 \%$ \\
$501-600 \mathrm{mg} / \mathrm{dL}$ & 2 & $12,5 \%$ \\
\hline Total & 16 & $100 \%$ \\
\hline
\end{tabular}

Dari data di atas diperoleh informasi bahwa rata-rata kadar gula darah sebelum mengkonsumsi kulit manggis yang tertinggi adalah 301-400 $\mathrm{mg} / \mathrm{dL}$ dengan prosentase $43,75 \%$. Sedangkan kadar gula darah yang terendah adalah 501 $600 \mathrm{mg} / \mathrm{dL}$ dengan prosentase $12,5 \%$.

Hasil analisa univariat kadar gula darah sebelum perlakuan diperoleh nilai rata-rata (mean) 392,63 , median 387,00 , modus 400 , range 335 , minimal 255 , dan maksimal 590, dengan standar deviasi 96,815. 
2. Kadar Gula Darah Setelah Mengkonsumsi Kulit Manggis Hasil pengukuran kadar gula darahsetelah pemberian kulit manggis

Tabel 2. Distribusi frekuensi kadar gula darah setelah Perlakuan

\begin{tabular}{ccc}
\hline $\begin{array}{c}\text { Kadar Gula } \\
\text { Darah }(\mathrm{mg} / \mathrm{dl})\end{array}$ & $\mathrm{f}$ & $\%$ \\
\hline $200-300$ & 5 & $31,25 \%$ \\
$301-400$ & 5 & $31,25 \%$ \\
$401-500$ & 4 & $25 \%$ \\
$501-600$ & 2 & $12,5 \%$ \\
\hline Total & 16 & $100 \%$ \\
\hline
\end{tabular}

Dari data di atas diperoleh informasi bahwa rata-rata kadar gula darah setelah mengkonsumsi kulit manggis yang tertinggi adalah 200-300 $\mathrm{mg} / \mathrm{dL}$ dan $301-400 \mathrm{mg} / \mathrm{dL}$ dengan persentase $31,25 \%$. Sedangkan kadar gula darah yang terendah adalah 501-600 $\mathrm{mg} / \mathrm{dL}$ dengan prosentase $12,5 \%$.

Hasil analisa univariat kadar gula darah setelah perlakuan adalah nilai mean 371,31 , median 362,50 , modus 230 , range 310 , minimal 230, maksimal 540, dan standar deviasi 93,851.

3. Pengaruh pemberian kulit manggis terhadap kadar gula darah

Tabel 3. Hasil Pengukuran Kadar Gula Darah sebelum dan sesudah diberi kulit manggis

\begin{tabular}{ccc}
\hline \multicolumn{2}{c}{$\begin{array}{c}\text { Rata-Rata Gula } \\
\text { Darah }\end{array}$} & \multirow{2}{*}{$\begin{array}{c}\text { Hasil T- } \\
\text { Test }\end{array}$} \\
\cline { 1 - 2 } Sebelum & Setelah & \\
\hline 392,63 & 371,31 & 0,001 \\
\hline
\end{tabular}

Dari hasil uji dengan Paired Ttest dengan taraf signifikansi $5 \%$ (0.05) didapatkan nilai $p$ sebesar
0.001 .nilai $p<0.05$, yang berarti Ha diterima dan Ho ditolak yang berarti ada pengaruh konsumsi kulit manggis terhadap penurunan kadar gula darah pada eksperimen tersebut.

\section{PEMBAHASAN}

1. Kadar Gula Darah Sebelum Pemberian Kulit Manggis

Kadar gula darah sebelum mengkonsumsi kulit manggis tertinggi pada kelompok 301-400 $\mathrm{mg} / \mathrm{dL}$ dengan persentase $31,25 \%$ dengan rata-rata kadar gula darah sewaktu sebelum mengkonsumsi kulit manggis371,31 mg/dL. Hasil tersebut menunjukkan bahwa sebelum mengkonsumsi kulit manggis, rata rata responden memiliki kadar gula darah yang tinggi atau di atas normal. Hasil tersebut juga memperlihatkan bahawa walaupun responden sudah melakukan penatalaksanaan diabetus melitus secara konvensional namun hasil pemeriksaan gula darah sewaktu masih tinggi. Dari wawancara dengan beberapa responden memang mengatakan mereka kurang telaten untuk melaksanakan diet, minum obat, atau olah raga. Hasil tersebut menunjukkan bahwa apabila prinsip penatalaksanaan diabetus melitus yang dikenal dengan 4 pilar DM tidak dilaksanakan dengan baik maka kadar gula darah tidak akan terkontrol dan cenderung naik. (Baradero, Dayrit, dan Siswandi, 2009)

2. Kadar Gula Darah Setelah Pemberian Kulit Manggis

Rata-rata kadar gula darah sewaktu (GDS) responden setelah mengkonsumsi kulit manggis adalah $392,63 \mathrm{mg} / \mathrm{dL}$, dengan persentase tertinggi pada nilai kadar gula darah 200 - 
$300 \mathrm{mg} / \mathrm{dL}$ sebanyak $31,25 \%$. Hasil tersebut menunjukkan bahwa terjadi penurunan nilai rata-rata kadar gula darah setelah responden mengkonsumsi kulit manggis. Hasil tersebut didukung dengan peningkatan persentase kelompok kadar gula darah 200 - $300 \mathrm{mg} / \mathrm{dL}$ dari 18,7\% naik menjadi $31,25 \%$. Penurunan kadar gula darah pada penderita diabetes mellitus ini sejalan dengan responden mengkonsumsi kulit manggis.

Menurut Yunitasari (2011), kulit manggis mengandung berbagai manfaat untuk menurunkan kadar gula darah terutama pada penderita diabetes mellitus.

3. Pengaruh Konsumsi Kulit Manggis Terhadap Penurunan Kadar Gula Darah

Berdasarkan hasil analisa pengukuran kadar gula darah pada eksperimen ini dengan mengunakan uji paired t-test dengan taraf signifikan 5\% (0.05) didapatkan nilai $P$ sebesar 0.001 , nilai $\mathrm{p}<0.05$, yang berarti $\mathrm{Ha}$ diterima dan Ho ditolak sehingga nilai tersebut menunjukan bahwa ada pengaruh konsumsi kulit manggis terhadap penurunan kadar gula darah pada eksperimen tersebut. Hasil uji statistik tersebut memberikan bukti empiris tentang efek atau manfaat kulit manggis dalam menurunkan gula darah. Sesuai dengan pendapat Yunitasari (2011) kulit manggis ini dapat menurunkan kadar gula darah karena kulit manggis menggandung xanthone, antosianin yang berkhasiat sebagai antioksidan dan antidiabetes yang dapat menurunkan kadar gula darah. Selain itu ekstrak kulit manggis mengandung lebih dari 90\% xanthone (campuran alfa- mangostin $80-90 \%$ dan gamamangostin 5-10\% ). Menurut Riyadi dan Sukarmin (2008), bahwa alfa-mangostin berguna menghambat kerja insulin alfa glukosidase di dalam saluran cerna sehingga dapat menurunkan hiperglikemia post prandial.

Hasil analisa statistik univariat juga mendukung hasil penelitian dimana terjadi penurunan nilai rata-rata gula darah sebelum mengkonsumsi kulit manggis 392,63 turun menjadi 371,31 . Data lain yang mendukung adalah terjadinya penurunan nilai modus sebelum mengkonsumsi kulit manggis 400 a menjadi 230 a demikian juga nilai median 387,000 turun menjadi 362,50 , termasuk nilai minimum sebelum mengkonsumsi kulit manggis 255 turun menjadi 230 dan nilai maximum sebelum mengkonsumsi kulit manggis 590 turun menjadi 540.

Hasil penelitian ini sesuai dengan hasil penelitian yang terdahulu yang dilakukan oleh Pasaribu, Sitorus dan Bahri (2012), pada penelitian tersebut diteliti tentang pengaruh ekstrak etanol kulit buah manggis (Garcinia mangostana L.) terhadap penurunan kadar glukosa darah. Data hasil pengujian KGD (Kadar Gula Darah) dengan dosis 50, 100 dan $200 \mathrm{mg} / \mathrm{kg}$ BB memberikan penurunan kadar glukosa darah yang signifikan dan berbeda bermakna dibandingkan kelompok kontrol dan tidak memberikan perbedaan yang nyata dengan glibenklamid dosis $0,65 \mathrm{mg} / \mathrm{kg}$ BB $(p>0,05)$. Pemberian ekstrak etanol kulit buah manggis dengan dosis $100 \mathrm{mg} / \mathrm{kg}$ BB memberikan hasil yang lebih baik terhadap penurunan kadar glukosa darah dibandingkan dengan dosis 50 $\mathrm{mg} / \mathrm{kg}$ BB dan $200 \mathrm{mg} / \mathrm{kg}$ BB.

Penelitian terdahulu yang relevan dengan hasil penelitian ini adalah 
penelitian dari Khotimah, Winarsih dan Arif (2011). Penelitian tersebut berjudul Potensi Ekstrak Metanol Kulit Manggis (Garcinia Mangosta L.) Terhadap Kondisi Glukosa Tinggi. Tujuan penelitian ini adalah untuk mengetahui potensi ekstrak metanol kulit manggis terhadap kondisi glukosa tinggi. Penelitian ini menggunakan metode experimental. Ekstrak kulit manggis diberikan bersama-sama dengan pemberian glukosa tinggi selama 3 hari.Hasil peneitian ini menunjukkan terjadinya penurunan distribusi ADMA (Asymmetric Dimethylarginine) pada sel endotel secara signifikan $(p=0,000 ; p<0,05)$ pada semua kelompok yang diberi ekstrak methanol kulit manggis.

Berdasarkan uraian di atas dapat disimpulkan bahwa, kulit buah manggis mempunyai efek sebagai antidiabetes yang dapat menurunkan kadar gula darah untuk para penderita penyakit diabetes mellitus.

\section{Keterbatasan Penelitian}

Pada penelitian ini masih kami temukan berbagai macam kelemahan terutama pada kurangnya waktu penelitian. Perlakuan hanya dilakukan selama 3 hari, sehingga efek dari perlakuan (konsumsi kulit manggis) belum begitu jelas terlihat. Walaupun hasil penelitian menunjukkan ada pengaruh yang signifikan konsumsi kulit manggis terhadap penuruan kadar gula darah, namun kadar gula darah tidak sampai pada nilai ambang normal.

\section{PENUTUP}

\section{A. Kesimpulan}

1. Kadar gula darah sebelum mengkonsumsi kulit manggis paling banyak pada rentang 301-400 $\mathrm{mg} / \mathrm{dL}$ dengan prosentase $\quad 43,75 \%$. Sedangkan prosentase kadar gula darah yang terendah pada kategori 501-600 mg/dL dengan prosentase 12,5\%, dengan nilai rata-rata 392,63.

2. Kadar gula darah setelah mengkonsumsi kulit manggis paling banyak pada rentang 200-300 mg/dL dan 301-400 $\mathrm{mg} / \mathrm{dL}$ dengan prosentase $31,25 \%$. Sedangkan prosentase kadar gula darah yang terendah pada kategori 501-600 $\mathrm{mg} / \mathrm{dL}$ dengan prosentase $12,5 \%$, dengan nilai rata-rata 371,31 .

3. Konsumsi kulit manggis berpengaruh secara signifikan untuk menurunkan kadar gula darah dengan hasil t-test 5\% (0.05) didapatkan nilai $P$ sebesar 0.001 , nilai $p<0.05$, yang berarti $\mathrm{Ha}$ diterima dan Ho ditolak sehingga nilai tersebut menunjukan bahwa ada pengaruh antara kulit manggis terhadap penurunan kadar gula darah.

\section{B. Saran}

1. Bagi Masyarakat Mempertimbangkan penggunaan kulit manggis terhadap penurunan kadar gula darah terutama pada penderita diabetes mellitus.

2. Bagi Institusi Pendidikan Kesehatan

Memasukkan materi tentang efektifitas kulit manggis terhadap penurunan kadar gula darah pada penderita diabetes mellitus.

3. Bagi Peneliti Selanjutnya
Penelitian selanjutnya
diharapkan dapat mengembangkan penelitian ini dengan menambah sampel dan lama (waktu) perlakuan 
DAFTAR PUSTAKA

Agoes, Azwar. Tanaman Obat Indonesia.Jakarta: Salemba Medika, 2010.

Baradero, Mary, M.W. Dayrit, dan Yakobus Siswandi. Seri Asuhan Keperawatan Klien Gangguan Endokrin. Jakarta: EGC. 2009.

Hidayat, Aziz Alimul. Riset Keperawatan dan Teknik Penulisan IImiah. Jakarta: Salemba Medika, 2003.

Riset Keperawatan dan Teknik Penulisan Ilmiah. Jakarta: Salemba Medika, 2008.

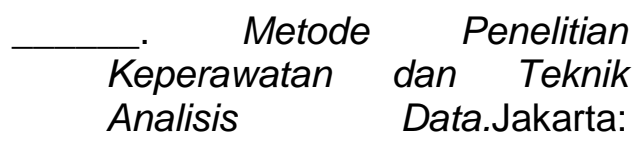

Salemba Medika, 2009.

Riwidikdo, Handoko. Statistik Penelitian Kesehatan dengan Aplikasi Program $R$ dan SPSS. Yogyakarta: Pustaka Rihama, 2009.

Riyadi, Sujono dan Sukarmin.Asuhan Keperawatan Pada Pasien dengan Gangguan Eksokrin dan Endokrin pada Pankreas. Yogyakarta: Graha IImu, 2008.

Septiatin, Entin. Apotek Hidup dari Tanaman Buah. Bandung: Yrama Widya, 2009.

Yunitasari, Liska. Gempur 41 Penyakit dengan Buah Manggis Khasiat dan Cara Pengolahanya untuk Pengobatan. Yogyakarta: Pustaka Baru Press, 2011.

Khotimah, Husnul, Sri Winarsih dan Maria Nisaul Arif. Potensi Ekstrak Metanol Kulit Manggis (Garcinia mangosta L.) Terhadap Kondisi Glukosa Tinggi. Skripsi. Semarang. UNBRA, 2010.

Pasaribu, Fidayani, Panal Sitorus dan Saiful Bahri. Uji Ekstrak Etanol Kulit Buah Manggis (Garcinia mangostana L.) Terhadap Penurunan Kadar Glukosa Darah. Sumatra Utara. Universitas Sumatera Utara, 2012.

1 Dosen AKPER Panti Kosala Surakarta

2 Dosen AKPER Panti Kosala Surakarta

3 Mahasiswa AKPER Panti Kosala Surakarta 